\title{
Stars in the sky: Pleiades invite plenitude — an ethnomathematics memoir in Central Brazil
}

\author{
Mariana Kawall Leal Ferreira
}

\begin{abstract}
This is a day, a month, a year, and a few decades - dry and rainy seasons included - in reallife mathematics of the Kisêdjê Indigenous People of the Wawi Territory, Central Brazil. According to the Kisêdjê, aka Suyá, the sun and the stars rule the sky, while people, animals, and plants create reality on earth. We are in the state of Mato Grosso, at 11 degrees, 45 minutes South latitude; and 53 degrees, 1 minute West longitude. Starting in 1981, this ethnomathematics memoir traces factual moments of my life as a mathematics educator in indigenous schools. Hands-on, real-life activities are included in the "Teacher's Notebook." This includes fishing expeditions, and excursions to local dispensaries and far away hospitals. My objective is to show that mathematics education, including map-making, provides important resources in the fight for sovereignty and autonomy of Indigenous Peoples in Brazil, the Americas, and worldwide.
\end{abstract}

Keywords: Ethnomathematics. Indigenous Peoples. Kisêdjê. Suyá. Brazil.

\section{Estrellas en el cielo: las Pléyades invitan a la plenitud - una memoria etnomatemáticas en el Centro de Brasil}

Resumen: Este es un día, un mes, un año y unas pocas décadas - incluidas las estaciones seca y lluviosa - en las matemáticas de la vida real de los pueblos indígenas Kisêdjê del territorio de Wawi, en el centro de Brasil. Según el Kisêdjê, también conocido como Suyá, el sol y las estrellas gobiernan el cielo, mientras que las personas, los animales y las plantas crean la realidad en la tierra. Estamos en el estado de Mato Grosso, a 11 grados, 45 minutos de latitud sur; y 53 grados, 1 minuto de longitud oeste. A partir de 1981, esta memoria etnomatemática rastrea momentos reales de mi vida como una educadora de matemáticas en escuelas indígenas. Las actividades prácticas de la vida real se incluyen en el "Cuaderno del maestro". Esto incluye expediciones de pesca y excursiones a dispensarios locales y hospitales lejanos. Mi objetivo, en el presente artículo, es mostrar que la Educación Matemática, incluida la elaboración de mapas, proporciona recursos importantes en la lucha por la soberanía y la autonomía de los pueblos indígenas en Brasil, las Américas y en todo el mundo.

Mariana Kawall Leal Ferreira Ph.D. in Medical Anthropology by the University of California at Berkeley and the University of California at San Francisco (UCB - UCSF, joint degree, 1996). Professor of Medical Anthropology, Human Rights, and Mathematics Education at San Francisco State University (SFSU), State of California, in the United States of America.

(iD) http://orcid.org/0000-0002-0124-7043 $\triangle$ marianalealferreira@gmail.com

Received in 11/09/2019 Accepted in 23/11/2019 Published in 04/03/2020
Palabras clave: Etnomatemáticas. Pueblos Indígenas. Kisêdjê. Suyá. Brasil.

\section{Estrelas no céu: Plêiades convidam a plenitude - uma memória etnomatemática no Brasil Central}

Resumo: Este é um dia, um mês, um ano, e algumas décadas - incluindo estaçōes seca e chuvosa - na Matemática da vida real do Povo Indígena Kisêdjê do Território Wawi, Brasil Central. Segundo os Kisêdjê, também conhecidos como Suyá, o sol e as estrelas regem o céu, enquanto pessoas, animais e plantas criam realidade na terra. Estamos no estado do Mato Grosso, a 11 graus e 45 minutos de latitude sul; e 53 graus, 1 minuto de longitude oeste. A partir de 1981, esta memória etnomatemática traça momentos factuais da minha vida como uma educadora de matemática em escolas indígenas. As atividades práticas da vida real estão incluídas no "Caderno do Professor". Isso inclui expediçōes de pesca, e excursōes a farmácias locais e hospitais distantes. Meu objetivo, no presente artigo, é mostrar que a Educação Matemática, incluindo a elaboração de mapas, fornece recursos importantes na luta pela soberania e autonomia dos povos indígenas no Brasil, nas Américas e no mundo.

Palavras-chave: Etnomatemática. Povos Indígenas. Kisêdjê. Suyá. Brasil. 


\section{Pleiades Invite Plenitude}

Peeking through the trees, from the comfort of my red cotton hammock, I recognize different constellations shining bright in the dark blue sky. I have learned from the Kisêdjê, aka Suyá, Indigenous People in Central Brazil, that when we first spot the Pleiades (ngroro in the Suyá language), setting in the West at night, heavy rainfall is giving way to light scant showers. Being an urban Brazilian woman, I am better at understanding lunar calendars in the female life-cycle. But now the position of the Pleiades has much more to tell: the end of the muggy rainy season, and the beginning of the dry and cold one. Fish is still scarce, as rivers are full, making it a difficult catch.

But like sweet potatoes and new manioc tubers in the gardens, river creatures will be plentiful once the Pleiades rise in the East at dawn and high in the sky in the very early morning. We look forward to smoking fish, including the favorite tucunaré (Chichla occelaris), and digging up turtle eggs buried in the white sand of the Xingu River ${ }^{1}$. Plenitude, predicted by the Pleiades, releases dry season songs (tepkradi), through which the Kisêdjê people invite their neighbors to much awaited ambedi (dry season) ceremonies.

Our conversations about the Pleiades, and the Orion Constellation, also high in the sky in ambedi, help the Kisêdjê and other students at the Diauarum (black panther, in the Kaiabi language) School create a "Xingu Calendar," depicting the huge variety of seasonal fruits, and game in the area.

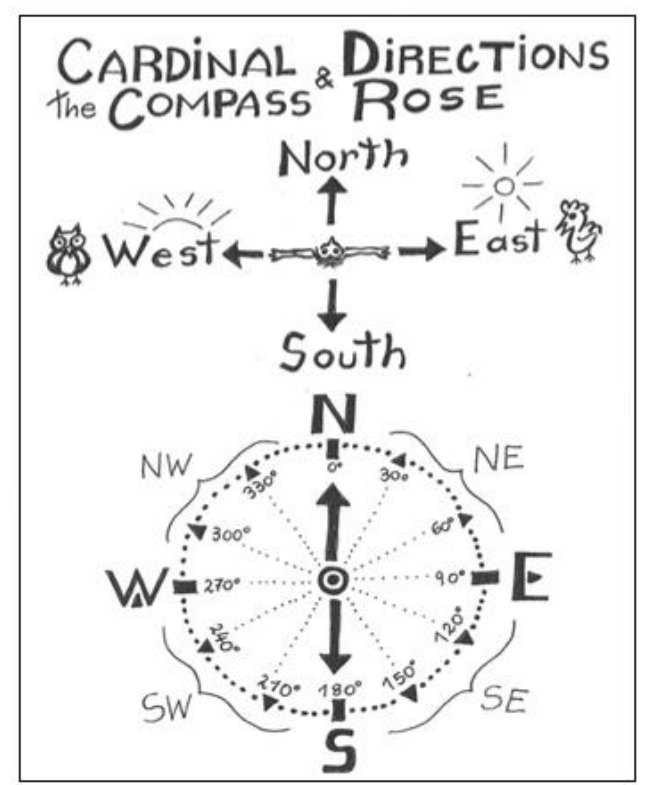

Figure1: Cardinal Directions \& the Compass Rose (MARIOLA PAEN, 2019²)

\footnotetext{
1 Tracajá in Portuguese, river turtle (Rodocnemis unifilis).

2 This drawing was created specifically for this article by Mariola Paen (2019). Funding was provided by the Sherwin Award at San Francisco State University, granted to Mariana K. L. Ferreira, in 2019.
} 


\section{Teacher's Notebook 1: Understanding Cardinal Directions \& the Compass Rose (Fig. 1.)}

Objective: Understand how the sun, a natural compass, and the compass rose can be used to determine direction in the surrounding environment, and find places on a map.

Activities: Determine your location on a map, using the compass rose. Build your own compass, drawing a compass rose with paper arrows.

1. If you stand with your right hand pointing to where the sun rises (East), and your left hand to where it sets (West), then you are facing North. The opposite is also true, and you will be facing South. Therefore, you can always find which direction you're going by facing the sun. In this respect, the sun is a natural compass.

2. Make a note of where you are, and where the sun is rising or setting. Are you facing your home, grandparents', best friend's, school or the river?

3. Now that you are able to determine that North is in front of you, and South is behind (Fig. 1), determine the 4 cardinal directions out loud: North, South, East, and West.

4. Draw a compass rose, with arrows pointing to the 4 cardinal locations. If you have access to a magnetic Compass, try out these cardinal points by walking around. Did you find intermediate positions - Northeast, Southeast, Southwest, and Northwest as shown in the compass rose?

5. If you have access to a map of your location at home or at school, locate the compass rose and try to find out where you are. Many times, the compass rose is just an arrow pointing North. Look around and situate yourself in terms of South, East, and West, too.

Discussion: Drawing maps and creating map books of indigenous territories and elsewhere for mathematics school activities require figuring out cardinal directions, for starters. It is a matter of survival: reading and creating your own maps is key to guaranteeing land rights, and thus autonomy and selfdetermination - that is, making decisions about your human rights. Recognizing and defending borders is hard work, especially as it was in the absence of GPS in the 1980s and early 1990s - and now still is in many territories in Brazil and beyond. In this respect, teaching about cardinal directions helps students gain insights about their surrounding environments and how to understand land ownership. This is particularly important for Indigenous Peoples today, as we write, since Brazil's new government in 2019 took a radical turn to the right, targeting Indigenous Peoples for owning "too much land."

Outcome: Map books. A plethora of atlases in the 1990s, related books and court cases advancing Indigenous Peoples' Land Rights, starting in the 1980s. These publications, by municipal, state, and governmental institutions, as well as indigenous associations, and teachers, were significantly advanced by the New 1988 Brazilian Constitution. The 1988 Brazilian Constitution asserted Indigenous Peoples' rights to their ancestral lands, and somewhat expedited the official demarcation of territories ${ }^{3}$.

Such books and documents have become prominent assets for the organized Indigenous movement in Brazil starting in the early 1980s. High profile court cases have guaranteed the demarcation and homologation of a high percentage of Indigenous Territories in Brazil since then (see ahead for the Wawi Territory court case).

\footnotetext{
${ }^{3}$ Map books, and related publications, include (see references cited): Cartilha de Geografia do Acre (CPI, 1992); Histórias de Verdade (SILVA \& RODRIGUES, 1992); Geografia Indígena Parque Indígena do Xingu (GAVAZZI, 1996); Área indígena Kapoto: laudo antropológico (LEA, 1997); Parque indígena do Xingú: laudo antropológico (LEA, 1997); Atlas Geográfico Indigena do Acre (BRASIL, 1998); Livros de Mapas de São Paulo (FERREIRA, 1999); Interesses Minerários em Terras Indígenas na Amazônia Legal Brasileira (RICARDO, 1999); A História da Aldeia Abelhinha (RURI'Ō and BIASE, 2000); Livros de Mapas da Associação Xavante Warã (FERREIRA \& SCHIESARI, 2002).
} 


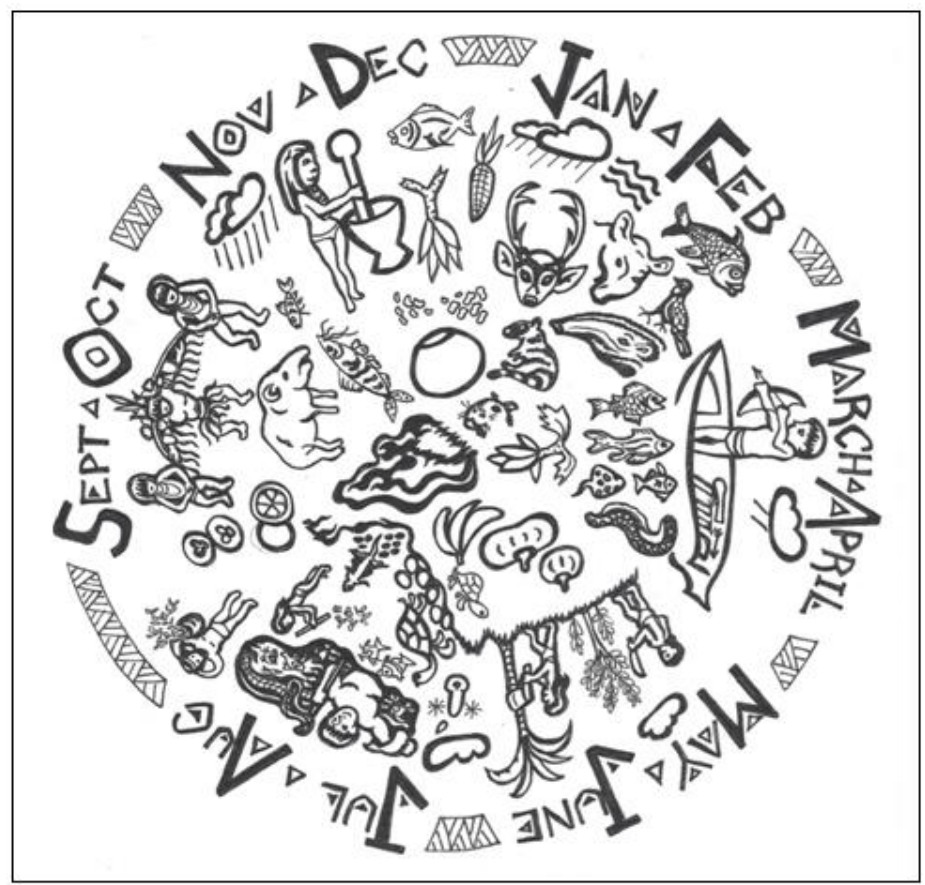

Figure 2: Xingu Calendar (MARIOLA PEN, 2019)

\section{Teacher's Notebook 2: Creating connections between stars, the moon, and real-life subsistence situations.}

Question: How does the Sun, the Pleiades and other stars or constellations, such as Orion, affect your everyday life? How about the Moon?

Activities: Create your own Calendar, showing how the stars and the moon affect life on Earth. Detail some of the main activities of each season, such as fishing, hunting and collecting fruits, planting the garden, and ceremonies.

Discussion: Starting in the 1980s, several schools in the Xingu Indigenous Territory (formerly known as Xingu Indigenous Park) produced their own calendars. In 1981, students in the Diauarum School (including the Kisêdjê), where I taught, created the first "Calendário do Xingu." Students chose to work in 12 groups, each representing a month of the calendar year. They also considered tribal affiliation in the groupings, which gave rise to lively discussions about fishing, hunting and gathering techniques, food taboos, and ceremonial practices. Mostly, it was a conversation about the Kisêdjê's, the Kaiabi's, and the Juruna's cosmologies or worldviews. In order to articulate their own cosmologies, each society resorts to diverse ways of organizing, classifying, and qualifying its own reality, and its respective cultural elements. (Figure 2 is a rendering of the cover of the Xingu Calendar in 1981. Each page of the calendar had a drawing of stars in the sky, and the subsistence activities associated with each month of the year, with a focus on plenitude.)

Anthropologist Bruna Franchetto (2002) wrote about the connection between earth and sky among the Karib-speaking Kuikúro people in the Xingu Indigenous Territory, who live slightly upstream from the Kisêdjê. The Kuikúro, with whom the Kisêdjê share cultural traits, also rely on the Pleiades, Orion and other constellations to predict fishing, hunting, gathering, and planting seasons. Franchetto (2002) calls nature's cyclical phenomena "natural 'clocks', which are generally configured according to mythical representations of space, the identification and movements of celestial bodies, geography, architecture, body schemes, and the perception of changes that occur in the environment" (p. 101, my translation).

It is precisely the specific procedures of counting, measuring time and space, reckoning kinship and the body, and ultimately organizing the world so it makes sense, that fashion and help create the mathematical knowledge of each people. 
In fact, Ubiratan D'Ambrosio (1990) defines Ethnomathematics as a research and learning program, which seeks to "identify techniques or even abilities utilized by distinct cultural groups in their search to explain, know, and understand the world that surrounds them" (p. 6, my translation).

Teacher's Note: Peoples or Populations? After the Declaration on the Rights of Indigenous Peoples was adopted by the United Nations in 2007, "Peoples" is the official international term, after "populations." Some governments still refer to Indigenous Peoples as "tribes" or "populations" for fear the term "peoples" implies the right to independent statehood according to international legislation. However, as reflected in the title of the UNDRIP, the term "peoples" is now applied to Indigenous Peoples with the full international significance of the concept. In Brazil, "Povos Indígenas" is the preferred term, used throughout the country (FERREIRA, 2013).

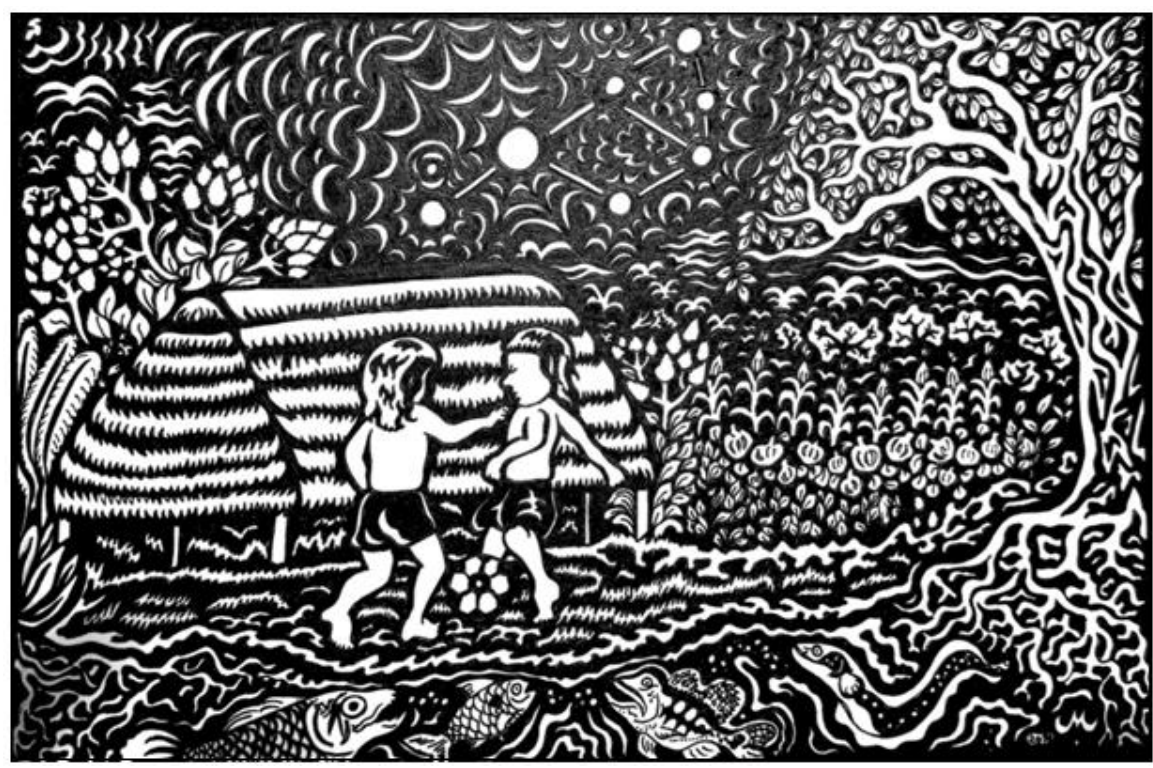

Figure 3: The seven Pleiades stars setting in the West at night during the dry season in Central Brazil, invite plenitude (MARIOLA PAEN, 2019)

Whispering through the treetops, warm wind enunciates ambedi, everyone's favorite (dry) season. In the absence of rain, fish feed hundreds of villagers and their guests attending traditional intertribal ceremonies in the Território Indígena do Xingu, state of Mato Grosso (dense woods, in Portuguese). The vegetation is thick and the trees are tall, transitioning between the brushy savannah of Central Brazil into the Amazon rainforest of the north. Now in the dry season, from May to October, white sand beaches and small islands that pop up in the middle of rivers become favorite hunting and fishing spots. Inland ponds and creeks are more easily reached in dugout canoes, or even on foot, with flood waters quickly retrieving in the absence of rain. I can't help but $\log$ in the steady reduction in cases of malaria due to less mosquitos and more steady use of mosquito nets.

In fact, Kisêdjê men, women, children and I are on a timbó fishing expedition near the Wawi River headwaters, located upstream from their village (Aldeia Ricô). It is early in the morning in July 1981, and I am 22 years old. We are carrying bundles of the timbó vine (Derris spp.) on our backs. 
(Timbó is temporarily toxic to fish and will allow us to catch them.) On our way, Kuiussi, the Kisêdjê headman, promptly spears a six-foot electric eel (Electrophorus electricus) in a small creek we cross over a log. His sons-in-law help him pull it ashore, avoiding its whipping tail which can deliver a 500-volt shock. Cut into harmless big chunks, the creature is soon roasted by the women on a makeshift grill by the lake, and stuffed into pieces of beiju (white tapioca flatbread).

Meanwhile, several young men get busy erecting a small dam to restrict the size of the fishing area to shallow waters. Others, on the shore, are working hard smashing the timbó vines with big sticks and pushing them into the pond, so the sticky sap starts intoxicating big and small catch. The poison works fast (but does not affect humans); children are already scooping up small fry in baskets. Young men are spearing bigger fish floating on their bellies from dugout canoes. It is a feast. At dusk we head back to the Xingu River and make our way to Aldeia Ricô, where elders smoke the catch.

I am struck by the swift process of distribution of small and large fish alike, taking into account the number of people per household, elders, and previous debts - in the spirit of an economy of reciprocity (aka gift-exchange or gift-giving). Division holds sway above addition, subtraction, and multiplication in the Diauarum School. It becomes clear that the three principles of reciprocity that Indigenous Peoples share - the obligation to give, to receive, and to reciprocate — are in action (LÉVI-STRAUSS, 1949; FERREIRA, 2015). Gift-giving is beautifully expressed by mathematics teacher Jaime Llullu Machineri cited in Ferreira (1998):

Love is also used by mathematics: those who love or feel compassion for a relative, help the person and share goods with others." Jaime Llullu Machineri. Mathematics teacher at the Aldeia Jatobá, on the Yaco River. Terra Indígena Mamoate, state of Acre in Northern Brazil (p. 3; my translation) ${ }^{4}$.

This is the information we gather on our fishing, and gathering expedition (as we visit old plantation sites), which is used in our mathematics classroom:

Table 1: Fish and reptiles in local rivers and flooded forest areas in the Xingu River basin the Kisêdjê subsist on (a selection)

\footnotetext{
${ }^{4}$ However, in this context, the economy of reciprocity is obstructed not only by capitalism and globalization, but also climate change. The report on consequences of The Belo Monte dam in the Brazilian Amazon, especially on fishing and agriculture, makes this very clear (PEZZUTI et al., 2018).
} 


\begin{tabular}{|l|l|l|}
\hline \multicolumn{1}{|c|}{ English } & \multicolumn{1}{|c|}{ Portuguese } & \multicolumn{1}{c|}{ Scientific name } \\
\hline peacock bass & Tucunaré & Cichla ocellaris \\
\hline golden trahira & jeju, traíra-pixuna & Oplerythrinus unitaeniatuas \\
\hline barred catfish, barred sorubim & surubim, surubim-pintado & Pseudoplatystoma fasciatum \\
\hline Piranha & Piranha & Pygocentrus and serrasalmus \\
\hline electric eel & peixe elétrico/poraquê & Electrophorus electricus \\
\hline string ray & Arraia & Elipsisurus stroglyopterus \\
\hline Matrincha & Matrinchã & Characidae \\
\hline redtail catfish & Pirarara & Phractocephalus \\
\hline iau leporinus & Piau & Leporinus \\
\hline yellow-spotted Amazon turtle & Tracajá & Lodocnemis unifilis \\
\hline
\end{tabular}

Source: Elaborated by the Author

Table 2: Staple vegetables and fruit harvested from old Kisêdjê village gardens

\begin{tabular}{|l|l|l|}
\hline \multicolumn{1}{|c|}{ English } & \multicolumn{1}{c|}{ Portuguese } & \multicolumn{1}{c|}{ Scientific name } \\
\hline manioc or cassava root & Mandioca & manihot esculenta \\
\hline Yam & cará, inhame & dioscorean esculenta \\
\hline sweet potato & batata doce & ipomea batatas \\
\hline Banana & banana da terra & musa parasidiaca \\
\hline Pineapple & Abacaxi & ananas comosus \\
\hline
\end{tabular}

Source: Elaborated by the Author 


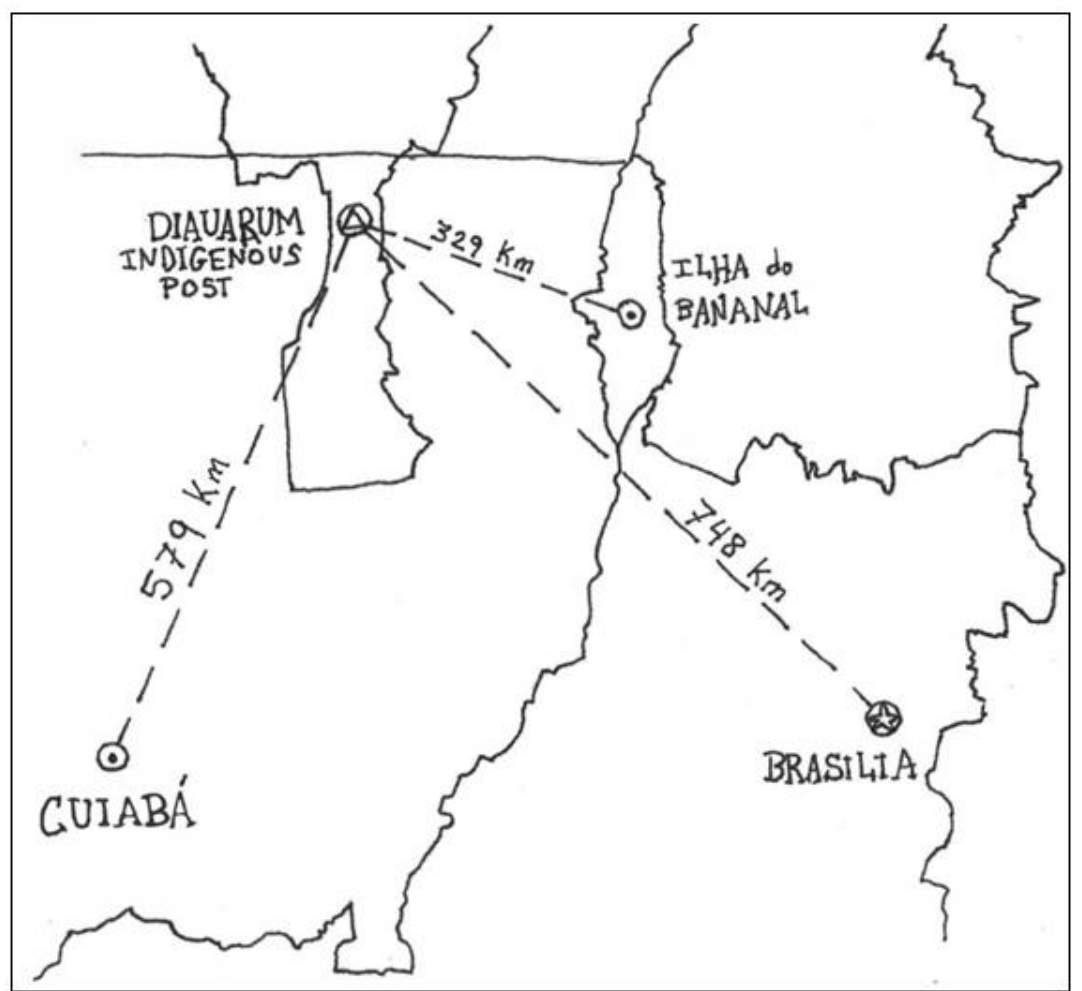

Figure 4. Distance from the Diauarum Indigenous Post, Xingu Territory in Mato Grosso, to hospitals in Cuiabá, llha do Bananal, and Brasilia (Map crated by Nathan Embretson ${ }^{5}$ )

\section{Malaria hits men, women, and children at the Ricô village}

Trekking back from the timbó fishing expedition, 23-year-old Donbeti Kisêdjê, a father of three, stumbles along the pathway, barely able to keep up with 50 people ahead. His body temperature reads $40^{\circ} \mathrm{C}$ (or $104^{\circ} \mathrm{F}$ ). Donbeti has shaking chills, profuse sweating, and nausea. He is carried in a hammock by family members to a canoe on the Xingu River. Upon reaching the Diauarum Indigenous Post, Donbeti, a health agent in training, seems to be in shock. His blood pressure is low. We immediately send out urgent radio messages to FUNAI neighboring headquarters in Cuiabá (capital of Mato Grosso), Goiânia (capital of Goiás), and Ilha do Bananal (state of Tocantins).

In a couple of hours, we hear from llha do Bananal: they have a doctor on call and malaria medication. But we still need an airplane. In despair, we consider distances from the Diauarum Post to our three desired destinations: Cuiabá, Goiânia, and llha do Bananal. Swift action is necessary and we wait for backup calls to save Donbeti. Given the fact that more than one million people die from malaria each year worldwide, every rescue is a victory ${ }^{6}$. Donbeti makes it to the

\footnotetext{
5 This drawing was created specifically for this article by Nathan Embretson (2019).

6 The reality of Malaria. Available in: https://www.unicef.org/media/files/MALARIAFACTSHEETAFRICA.pdf . Malaria kills one child every 30 seconds, about 3000 children every day. Over one million people die from malaria each year,
} 
Diauarum Post late in the evening. The next morning we are on the radiophone figuring out how long each flight would take to the three different destinations.

Teacher's Notebook: Which is the best flight time for Donbeti, considering the urgency of his situation, and distances to the three viable destinations?

Objective: Using addition to solve real-life problems.

Plan: Estimate the distances between the Diauarum Indigenous Post, located in northernmost TIX, and the three viable destinations for emergency health care.

Distances: Diauarum Indigenous Post to: Cuiabá (578 km); llha do Bananal (329 km); Brasilia (748 km).

Speed: Cessna airplanes travel at about $200 \mathrm{~km}$ per hour

Equation: time $=$ distance over/divided by speed $(t=d / s)$

Questions: What would be the time spent From the Diauarum Post to each different location? Which one would you take, knowing that both llha do Bananal and Cuiabá may not be the most reliable, because there are fewer airplanes available for emergency rides?

Additional Information: How many people have bed nets in your community? The use of mosquito nets (especially insecticide-treated) can reduce malaria by $50 \%$ in areas of high transmission.

Extra activity 1: If one million people die of malaria every year around the world, how many, in average, die per day? Per hour? Find out how many people suffer from malaria in your area or country. What is being done about it? Are mosquito nets available? And what kind of malaria? Vivax or falciparum?

Extra activity 2: Convert degrees Celsius to Fahrenheit.

Equation: To convert temperatures in degrees Celsius to Fahrenheit, multiply $C^{\circ}$ by 1.8 and add 32 . For example: Take Donbeti's temperature mentioned above $\left(40^{\circ} \mathrm{C} \times 1.8\right)+32=104^{\circ} \mathrm{F}$.

Hired to teach Portuguese and mathematics by the National Indian Foundation (FUNAI), I double as a practical nurse when outside health professionals are unavailable in the northern Xingu area - known as Baixo (Low) Xingu. Rivers flow North into the Amazon River. I work in the Diauarum Indigenous Post, an administrative unit of FUNAI, with a registered nurse, when she is in the area. Local Indigenous health agents help monitor infectious-contagious diseases, such as malaria and tuberculosis, malnutrition, dehydration and other ailments in children. I learn how to draw blood and scan for malaria and TB in our microscopes, donated by the Escola Paulista de Medicina in São Paulo (now Federal University of São Paulo).

But I am a school teacher, not a registered nurse. So I study everyday what do to in the absence of a health professional, using the Spanish (and first) edition of Cuando No Hay Doctor (WERNER, 1973), sent by my father Jorge. I am often at a loss, and overworked day and night making house visits and dispensing medication for malaria and tuberculosis. Despite the abundance of food and water in Xingu area, in the 1980s several Indigenous Peoples, mainly

mostly children under five years of age, with 90 per cent of malaria cases occurring in Sub-Saharan Africa. An estimated 300-600 million people suffer from malaria each year. Accessed on February 16, 2020. 
children in the Xingu Territory, but also throughout Brazil, are suffering from malnutrition and dehydration - in many cases because of malaria, pulmonary, and TB infections. The idea that comida de caraíba (white people food) is better than comida de índio (indian food) has become pervasive since at least 19617.

That was when the Parque Nacional do Xingu (as it was originally called) was created by the Brazilian government, to conveniently confine 17 different Indigenous nations into a "Park." Indigenous Peoples, such as the Panará and the Kaiabi, were brought from further north to the Xingu River basin, where other native societies already lived. The well-documented initiative of "relocation" and "assimilation," practiced worldwide, set free Indigenous lands around the Território Indigena do Xingu (TIX) for corporate multinational interests (cattle and agricultural developments, mostly). Such is the case of the Kisêdje people, whose Wawi ancestral land was cut off from the borders of TIX in 1961. In 1998 the Kisêdje won a landmark court case against big landowners, discussed ahead.

Meanwhile, it is essential to point out that, yes, hunting, gathering, fishing and the ability to plant gardens has afforded the Kisêdjê access to, and development of, food sources. However, climate change, and the encroachment of big farmers and multinational corporations that practice mining and deforestation (using toxic chemicals), and now build hydroelectric dams (Belo Monte, essentially), have limited the people's ability to rely exclusively on an abundant ecosystem, as they once did. "Diseases of civilization," such as diabetes and cancer, in addition to malaria and tuberculosis, are now commonplace (FERREIRA \& LANG, 2006). This is why the Oral Rehydration Solution is included below in our real-life mathematics classroom activities.

Teacher's Notebook: How to prepare Oral Rehydration Solution. It is used to prevent and treat dehydration, especially caused by high fever, severe vomiting and/or diarrhea in children.

Objective: Learn how to prepare a simple Oral Rehydration Solution with drinking water, sugar and salt, which can save lives.

Plan: Gather the ingredients listed below. For drinking water, you can boil the water and cool it down ahead of time - if you don't know whether your water is safe to drink.

Note 1: We are using the Metric system here, used worldwide, with information on how to convert it to the U.S. Standard system (aka the Imperial system, developed in Britain).

Preparation Method for the Oral Rehydration Solution (ORS ${ }^{8}$ :

${ }^{7}$ Comida de caraiba means, in general: rice, beans, beef or chicken, or a fried egg. Government food staples sent to Xingu, and other Indigenous territories in Brazil have included: canned sardines, beef jerky, cooking oil, pasta, tomato paste, salt and sugar, and powdered milk. The same is true, broadly speaking, of commodities sent to "Indian reservations" in the United States of America.

${ }^{8}$ This Oral Rehydration Solution plan was devised by, and included in: Ferreira (1998, p. 144-149): "Enfim, as contas matemáticas!". 


\section{Wash your hands.}

2. Place 1 liter (4 cups) of drinking water into a clean recipient.

3. Add 1 small teaspoon of salt (4 to $5 \mathrm{ml}$ ). Note that in the metric system, $\mathrm{ml}$ means milliliter, equal to 1 thousandth $(1 / 1000)$ of a liter.

4. Add 4 teaspoons of sugar (about $20 \mathrm{ml}$ ) and stir very well.

5. Check the chart below for the exact amount of ORS needed to treat dehydration, according to the weight of each child or adult. Weight measurements are given in kilograms (kgs) and pounds (lbs). The heavier the person is, the more rehydration solution is needed. The preparation method remains the same for children and adults.

Additional Information: Signs of dehydration - when the body does not have enough water to function properly - include: dry mouth, eyes not making tears, little or no sweating, muscle cramps, nausea and vomiting, diarrhea, and weakness. These can be life-threatening symptoms.

Note 2: Small children can sip frequently at the solution throughout the day, provided they take the minimal amount required per hour, as stated in the chart below.

Critical Questions for practice. Consult the ORS calculation in Table 3 below and answer:

a) What is the amount of ORS that a child who weighs $5 \mathrm{kgs}$ should take?

b) What is the amount of ORS in $\mathrm{ml}$ that a child weighing 22 lbs should take? And in cups?

c) How many cups of ORS should a child who weighs 20 kilos drink? How often?

d) How many liters of ORS should an adult weighing 50 kilos drink? And how often?

How to calculate a life-saving Oral Rehydration Solution (amount per person)

Table 3: Oral Rehydration Solution (ORS) Calculation Chart

\begin{tabular}{|c|c|c|c|c|c|}
\hline $\begin{array}{l}\text { Weight in } \mathbf{~ g g} \\
\text { or lbs }\end{array}$ & $\begin{array}{l}3 \text { to } 4 \mathrm{~kg} \\
6.5 \text { to } 9 \mathrm{lbs}\end{array}$ & $\begin{array}{l}5 \text { to } 8 \mathrm{~kg} \\
9 \text { to } 18 \mathrm{lbs}\end{array}$ & $\begin{array}{l}9 \text { to } 11 \mathrm{~kg} \\
19 \text { to } 25 \mathrm{lbs}\end{array}$ & $\begin{array}{l}12 \text { to } 14 \mathrm{~kg} \\
26 \text { to } 31 \mathrm{lbs}\end{array}$ & $\begin{array}{l}15 \text { to } 50 \mathrm{~kg} \\
33 \text { to } 110 \mathrm{lbs}\end{array}$ \\
\hline $\begin{array}{l}\text { During first } \\
4 \text { to } 6 \text { hours } \\
\text { of } \\
\text { dehydration } \\
\text { (in ml or tsp) }\end{array}$ & $\begin{array}{l}200 \text { to } 400 \mathrm{ml} \\
\text { or } \\
0.7 \text { to } 1.5 \text { cups }\end{array}$ & $\begin{array}{l}400 \text { to } 600 \mathrm{ml} \\
\text { or } \\
1.5 \text { to } 2.5 \text { cups }\end{array}$ & $\begin{array}{l}600 \text { to } 800 \mathrm{ml} \text { or } \\
2.5 \text { to } 3.5 \text { cups }\end{array}$ & $\begin{array}{l}800 \text { to } 1000 \mathrm{ml} \\
\text { or } \\
3.5 \text { to } 4.0 \text { cups }\end{array}$ & $\begin{array}{l}1200 \text { to } 4500 \\
\mathrm{ml} \text { or } \\
4.0 \text { to } 19 \text { cups }\end{array}$ \\
\hline \multicolumn{6}{|c|}{ Note: If diarrhea continues, use method 1 or 2 below to prevent recurring dehydration } \\
\hline $\begin{array}{l}\text { Method } 1 . \\
\text { After every } \\
\text { diarrhea give }\end{array}$ & $\begin{array}{l}50 \mathrm{ml} \\
\text { or } \\
0.2 \text { cup }\end{array}$ & $\begin{array}{l}100 \mathrm{ml} \\
\text { or } \\
0.4 \text { cup }\end{array}$ & $\begin{array}{l}120 \mathrm{ml} \\
\text { or } \\
0.5 \text { cup }\end{array}$ & $\begin{array}{l}150 \mathrm{ml} \\
\text { or } \\
0.7 \text { cup }\end{array}$ & $\begin{array}{l}200 \text { to } 400 \mathrm{ml} \\
\text { or } \\
0.7 \text { to } 1.5 \text { cups }\end{array}$ \\
\hline $\begin{array}{l}\text { Method } 2 \text {. } \\
\text { Throughout } \\
24 \text { hours give }\end{array}$ & $\begin{array}{l}400 \mathrm{ml} \\
\text { or } \\
0.7 \text { to } 1.5 \text { cups }\end{array}$ & $\begin{array}{l}600 \mathrm{ml} \\
\text { or } \\
2.5 \text { cups }\end{array}$ & $\begin{array}{l}800 \mathrm{ml} \\
\text { or } \\
3.5 \text { cups }\end{array}$ & $\begin{array}{l}1000 \mathrm{ml} \\
\text { or } \\
4 \text { cups }\end{array}$ & $\begin{array}{l}2000 \mathrm{ml} \\
\text { or } \\
8 \text { cups }\end{array}$ \\
\hline
\end{tabular}

Source: Ferreira (1998, p. 145)

Teacher's note: Today, Indigenous Peoples number more than 370 million individuals and live in more than 90 different countries on every continent. They have inherited and retained social, cultural, economic, and political characteristics that are distinct from those of the dominant societies in which they 
live. In some countries, such as Ecuador and Bolivia, Indigenous Peoples form the majority of the population; in others, including Norway and the United States, they comprise small minorities. Most Indigenous Peoples, including the Kisêdjê in Brazil and the Mapuche in Chile, strive to preserve traditional ways of life, while others seek greater participation in mainstream society. Despite their vast geographic and cultural differences, Indigenous Peoples share a common experience: they are among the most disadvantaged and vulnerable groups of people in the world today (FERREIRA, 2013, p. 7).

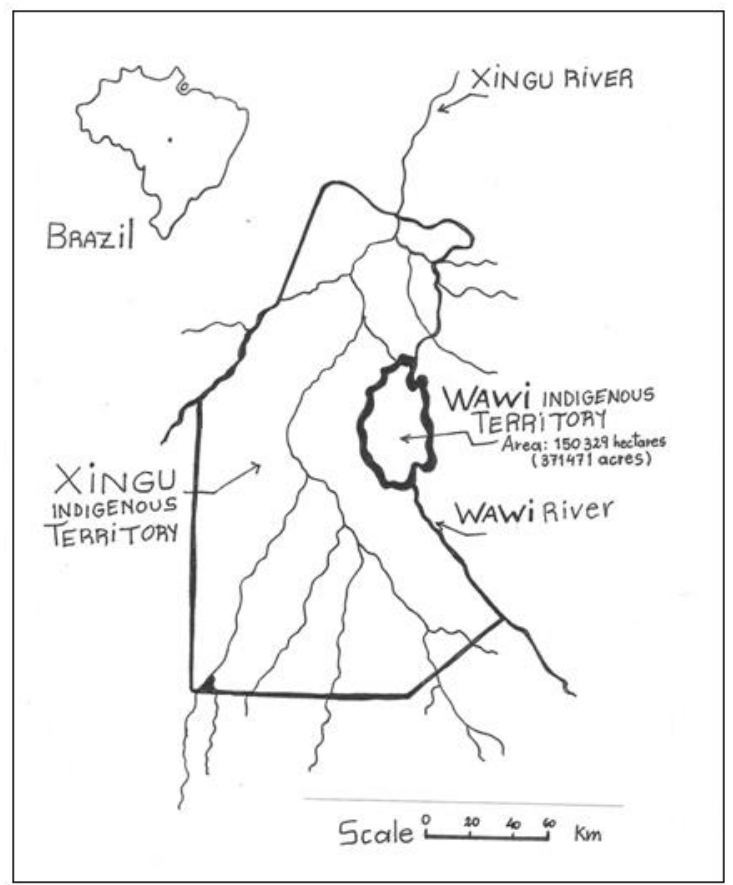

Figure 5: Wawi Indigenous Territory, ancestral Territory of the Kisêdjê people, adjacent to the Xingu Indigenous Territory (MARIOLA PAEN, 2019, adapted from RICARDO, 2000, p. 628)

\section{Twelve underwater animals help the Kisêdjê win the court case Hélio Salvador Russo FUNAl and Kuiussi Suyá in $1998^{9}$}

Never in my wildest dreams, did I see it coming: The successful repossession (and rebuttal to farmers) of the Terra Indigena (TI) Wawi, being attributed by the Kisêdjê to 12 underwater animals, including the anaconda (Eunectes murinus), the sting ray (Elipisurus strogylopterus), and the river turtle (Podecnemis expansa); (Figure 6). Their transformative energy "opened the white men's heads" to the existence of different worldviews - and, consequently, to very diverse mapmaking and land distribution systems (FERREIRA, 2015, p. 59).

\footnotetext{
9 Court case \# 95.0001396-7, initiated by farmer Hélio Salvador Russo in 1998, against the Fundação Nacional do Indio (FUNAI) and Kuiussi Suyá. Response filed by Expert Witness Dr. Mariana Kawall Leal Ferreira on Oct. 20, 1998. Victory on the part of the Kisêdjê (aka Suyá) required that farmers leave the TI Wawi, although the farmers were compensated by FUNAI for their "losses" - yet another corruption case in the Brazilian judiciary system.
} 
What startles me the most, as the official anthropology expert witness, is the fact that a Chief Justice in the state of Mato Grosso has accepted our argument that three political and ceremonial Kisêdjê leaders - Kuiussi, Romdó, and Intoni Suyá (as named in the court case), have claimed that their knowledge and power stems from 12 animals and supernatural creatures shown below (Fig. 6 and Table 4).

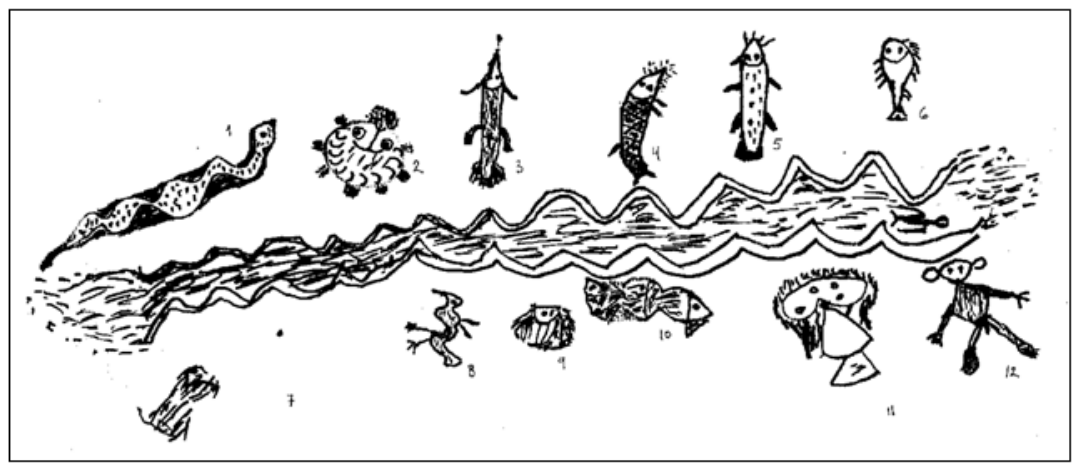

Figure 6: The 12 underwater creatures (INTONI SUYA in FERREIRA, 2015, p. 68)

Strikingly, these fish-like beings appear as both animal and human in Kisêdjê cosmology. Although in 1998 the Kisedjê (Suyá) won in the court system the official possession of their Wawi territory, adjacent to the (then called) Xingu Indigenous Park, farmers who "owned" or held property titles to the Kisedjê/Suyá (Wawi) land still claimed they deserved compensation for "lost profits" of lands they illegally owned, but "invested" in.

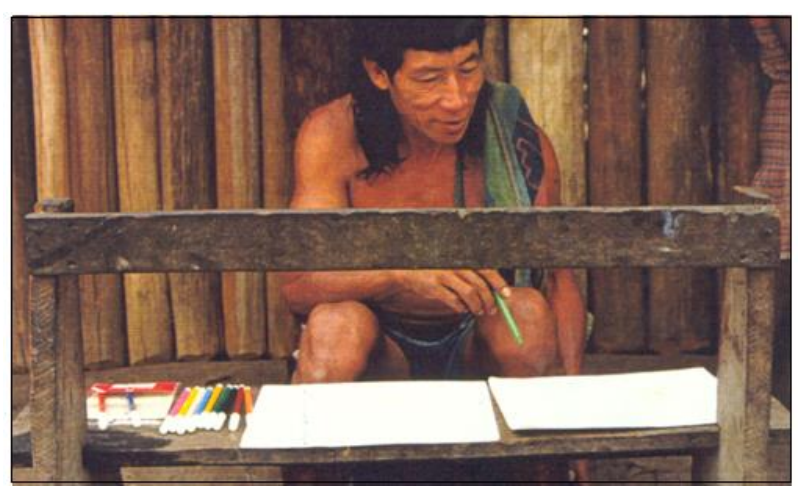

Figure 7: Intoni Suyá, drawing the 12 underwater creatures: "We learn from water creatures how to protect our land" (Photo by Mariana K. L. Ferreira, 1998)

Table 4: The 12 underwater creatures and their powers, who taught the Kisêdjê how to act accordingly in order to save the Wawi Indigenous Territory in court from big land owners

\begin{tabular}{|l|l|l|}
\hline \multicolumn{1}{|c|}{ Portuguese } & \multicolumn{1}{c|}{ English } & \multicolumn{1}{c|}{ Power } \\
\hline 1. Peixe flauta & Flute fish & Only moves when other fish do \\
\hline 2. Chefe do peixe & Boss of the flute & Kisêdjê leaders can overrule the flute fish and act in \\
\hline
\end{tabular}




\begin{tabular}{|l|l|l|}
\hline flauta & fish & isolation if needed \\
\hline 3. Peixe preto & Black fish & $\begin{array}{l}\text { Surfaces as a canoe, the Kisêdjê's main means of } \\
\text { transportation }\end{array}$ \\
\hline 4. Peixe agulha & Needle fish & $\begin{array}{l}\text { Floats on the water's surface, without raising } \\
\text { suspicion, to survey what's taking place on land }\end{array}$ \\
\hline 5. Peixe peneira & Sieve fish & $\begin{array}{l}\text { Swims swiftly against the current without being } \\
\text { deterred }\end{array}$ \\
\hline 6. Sucuri & Anaconda & $\begin{array}{l}\text { Strong and fearless. Created rivers by breaking } \\
\text { underground waters loose }\end{array}$ \\
\hline 7. Peixe cavalo & Horse fish & $\begin{array}{l}\text { Strong smelling horse that is able to survive } \\
\text { underwater and in other hostile environments }\end{array}$ \\
\hline 8. Socó & Stork fish & Can also fly, surveying the land from the sky \\
\hline 9. Peixe cabaça & Gourd fish & $\begin{array}{l}\text { Disguises itself in the mud and pretends to know } \\
\text { nothing, but is very knowledgeable }\end{array}$ \\
\hline 10. Ser humano & Human being & $\begin{array}{l}\text { Very powerful. Lives underwater, and can tell all fish } \\
\text { to move together at any given time }\end{array}$ \\
\hline 11. Arraia & Sting ray & $\begin{array}{l}\text { Lives underground and also underwater. Can become } \\
\text { invisible and sting when threatened }\end{array}$ \\
\hline 12. Ser humano & Human being & $\begin{array}{l}\text { Another human being who also lives underwater and } \\
\text { watches out for the headwaters, lagoons and rivers of } \\
\text { the Kisêdjê people. All humans come from the waters }\end{array}$ \\
\hline
\end{tabular}

Source: Ferreira (2015, p. 68-69)

The Kisêdjê are notorious for their victory regaining control of their ancestral Wawi territory in the Hélio Salvador Russo FUNAl and Kuiussi Suyá 1998 court case. Wawi, their ancestral territory, was left outside the official demarcation of the (then called) Xingu National Park in 1961 (Fig. 5). Today, about 450 Kisêdjê live in the TI Wawi (contiguous to the TI Xingu), after its official demarcation in 1998.

The Kisêdjê have been very active with respect to environmental issues affecting their rivers and forests. They have been strongly opposed to the aggressive invasion and deforestation of their lands by soybean farmers, like other Indigenous and riverine communities in Brazil. And they are adamantly against the Belo Monte dam because of its tremendous environmental impact. Mathematics education, in particular map-making skills, and the ability to organize in tandem with other Indigenous Peoples nationwide, have been vital to their success in guaranteeing ancestral land rights. 
The Associação Indígena Kisêdjê (AIK) has invested in sustainable agricultural projects in partnership with other local and national organizations. In 2006, a successful initiative took off involving the plantation of pequi (Caryocar Brasiliense) trees, which is native to the area. The Pequi fruit is a staple of the Kisêdjê diet, and also used as a body moisturizer, medicine for respiratory problems, and insect repellent. Today, this successful project, part of the "Projeto Sociobiodiversidade Produtiva no Xingu," has expanded to more than 60 hectares of pequi trees, with the extraction of pequi oil as a sustainable source of income for the Kisêdjê people. Hopefully, the project will become self-sufficient and independent from federal funding, given the drastic cuts to the "Fundo Amazônia" by the current (2019) President of Brazil.

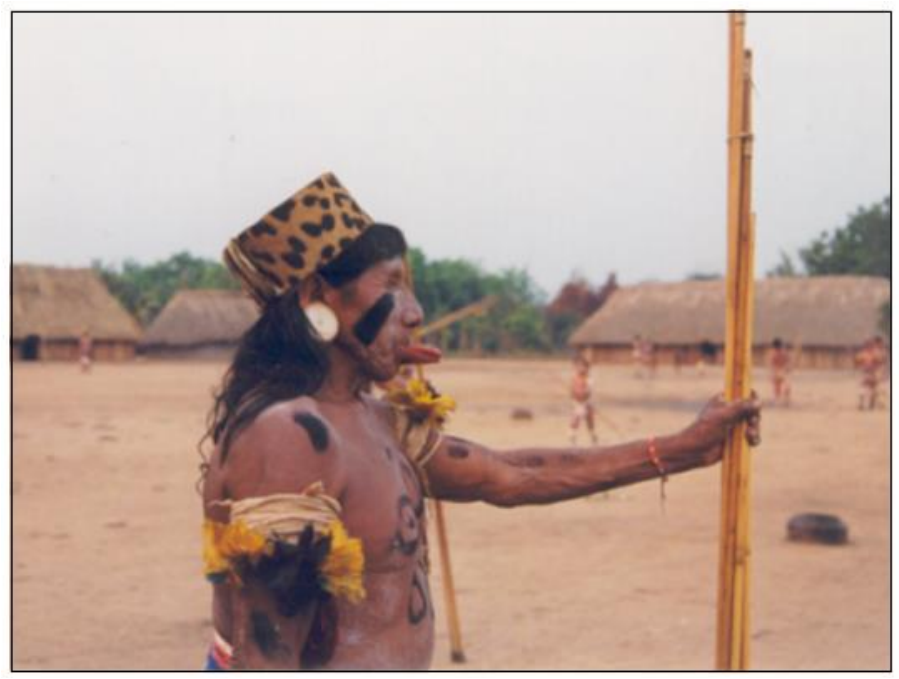

Figure 8: Romdó Kisêdjê, the shaman-jaguar, surveys Wawi ancestral territory (Photo by Mariana Ferreira (1998)

\section{Afterthought: Successes of Indigenous Mathematics Education}

Rowing against the current

That is what I never thought I needed to do when crossing the Xingu river from the Diauarum Indigenous Post to the white-sanded beach across, looking for turtle eggs or crabs, in my tiny dug-out canoe with my dog Maçã in the early 1980s. She wasn't much help, so I thought, other than barking at animals (deer, tapir, turtles, snakes) swimming around us, and keeping us company. I just thought I could keep the creatures astray by hitting them on the head with my paddle (that's when I'd lose balance and fall in the water). But I did learn a precious canoeing lesson from Maçã, when we first capsized: Swim upstream in order to land where you want to be (downstream). Unlike me, the dog had a great sense of direction, because she understood the power of the current you have to fight against. I often thought about this lesson when I was stranded downstream, walking for hours on the margins of the Xingu river, hoping to fetch a ride from canoes 
or motorboats headed upriver back to the Diauarum Post in the Xingu Territory, where I worked. Maçã was already waiting for me there. I was told that she knew how to navigate the river: swim upstream for survival. What a great lesson.

\section{Swim upstream for survival}

I thought of this lesson everyday in the mathematics classroom at the Diauarum School in northernmost Xingu Territory. Fight against the monsters (Iutar contra os monstros),_as one of my students put it, referring to the Brazilian military dictatorship (1964-1985), which kept a close watch on our "subversive" activities of learning how to read and write. All of my Paulo Freire books had fake covers (following my father's advice). First readers we wrote and map books we drew were scrutinized by FUNAI. In retaliation, we received no supplies and could only rely on family donations from São Paulo.

\section{Swim upstream}

Create our own pedagogical materials, which we did, using an alcohol-run mimeograph to print reading matter — primarily the Memória do Xingu (Xingu Memory) monthly newsletter, and annual Xingu Calendars, mentioned above. We disguised history as myth. Copies of maps were taken by informal sympathizers, flown in and out of Xingu for other reasons, just in case originals were lost or destroyed. Radio messages were sent in different languages, promoting our school curricula and asking for help from nearby schools. We attracted students from faraway villages in the Xingu Territory: North and South students flocked from the Mēbêngôkre (aka Kayapó), further North (who now live in their own Kapoto Territory and elsewhere); and South, such as the Trumai, Kukúro, Kalapalo, and other peoples from the Baixo Xingu. One by one, Indigenous schools started mushrooming in the Xingu Indigenous Territory, with support coming mostly from the Instituto Socioambiental headquarters in São Paulo, and private donations.

This is the result of the strong Indigenous Peoples' Movement in Brazil, starting in the 1970s, during the dictatorship, which led to the birth of multiple indigenous organizations and NGOs that still prevail today. I began volunteering at the Comissão Pró-Índio de São Paulo, in 1977. COPIAR - "Comissão dos Professores Indígenas do Amazonas," represents more than 80 Indigenous organizations today, fighting for education equity and social justice in the Brazilian Amazon. And there are many, many others.

Now, what are academics doing about this struggle? Are we, mathematics educators fighting for Indigenous Peoples' rights to quality mathematics education? In general, yes. Ethnomathematicians are increasingly proposing new mathematics curricula for schools 
(indigenous or not), based on real-life situations, as mentioned above. However, some high-profile articles still ask: "Is There Mathematics in the Forest?" (ALMEIDA, 2019). The author, an anthropologist, offers several mathematical equations based on kinship as evidence that, yes, there is "mathematics in the forest."

Kinship relationships can be coded and reckoned, as the argument goes, and thus used as predictable outcomes of mathematical reasoning. True, any everyday activity that involves people in action can be translated into an algorithm, by using social relationships as numerals, as I have argued before. The beauty of ethnomathematics, however, as my father Jorge Leal Ferreira - a physicist and mathematician at heart - called the "pearls of mathematics," is the fact that mathematics is what we do in everyday life.

In this respect, we invite your eye to gaze at stars, look down to the earth, above at elders, over to the children, and realize that we are all ethnomathematicians, deep inside.

\section{References}

ALMEIDA, Mauro William Barbosa. Is there Mathematics in the forest? HAU: Journal of Ethnographic Theory, v. 9, n. 1, p. 86-98, 2019.

BRASIL. Ministério da Educação. Secretaria de Educação Fundamental. Atlas geográfico indígena do Acre. Rio Branco: Comissão Pró-Índio do Acre, 1998.

Comissão Pró-Índio do Acre (CPI ACRE) Geografia Indígena. Professores Indígenas do Acre. Rio Branco: CPI-Acre, 1992.

D'AMBROSIO, Ubiratan. Etnomatemática: arte ou técnica de conhecer e aprender. São Paulo: Ática, 1990.

FERREIRA, Mariana K. Leal. Mapping Time, Space and the Body: Indigenous Knowledge and Mathematical Thinking in Brazil. Rotterdam: Sense Publishers, 2015.

FERREIRA, Mariana Kawall Leal. Madikauku: os dez dedos das mãos - Matemática e povos indígenas no Brasil. Brasília: Ministério da Educação / Secretaria de Educação Fundamental, 1998.

FERREIRA, Mariana Kawall Leal. (Org.) Livros de Mapas de São Paulo. Brasília: Ministério da Educação / Secretaria de Educação Fundamental, 1999.

FERREIRA, Mariana Kawall Leal. Acting for Indigenous Rights: Theatre to Change the World. Minnesota: University of Minnesota Human Rights Center, School of Law, 2013.

FERREIRA, Mariana Kawall Leal; LANG, Gretchen C. (Ed.). Indigenous Peoples and Diabetes: Community Empowerment and Wellness. Durham: Carolina Academic Press, 2006. 
FERREIRA, Mariana Kawall Leal; SCHIESARI, Luís. Livro de Mapas da Associação Xavante Warã. Mato Grosso: Terra Indígena Sangradouro, Aldeia Idzô'uhu, 2002.

FRANCHETTO, Bruna. Céu, Terra, Homens. O calendário Kuikúro. In: FERREIRA, Mariana Kawall Leal (Ed.). Idéias matemáticas de povos culturalmente distintos. São Paulo: FAPESP/MARI/Global, 2002, p. 101-118.

GAVAZZI, Renato Antônio. (Org.). Geografia indígena: Parque Indígena do Xingu. São Paulo: Instituto Socioambiental, 1996.

LEA, Vanessa Rosemary. Área indígena Kapoto: laudo antropológico. Campinas: Instituto de Filosofia e Ciências Humanas da Universidade Estadual de Campinas (IFCH/Unicamp), 1997.

LEA, Vanessa Rosemary. Parque indígena do Xingú: laudo antropológico. Campinas: Instituto de Filosofia e Ciências Humanas da Universidade Estadual de Campinas (IFCH/Unicamp), 1997.

LÉVI-STRAUSS, Claude. The Elementary Structures of Kinship. Boston: Beacon Press, 1949.

PEZZUTI, Juarez; CARNEIRO, Cristiane; MANTOVANELLI, Thais; GARZÓN, Biviany Rojas. Xingu, o rio que pulsa em nós. São Paulo: Instituto Socioambiental (ISA), 2018.

RICARDO, Carlos Alberto. (Org.). Povos Indígenas no Brasil, 1996/2000. São Paulo: Instituto Socioambiental, 2000.

RICARDO, Fany Pantaleoni. (Org.). Interesses minerários em Terras Indígenas na Amazônia Legal brasileira. São Paulo: Instituto Socioambiental, 1999.

RURI'õ, Lucas; BIASE, Helena de Stilene. Daró Idzô'uhu Watsu'u. A História da Aldeia Abelhinha. São Paulo: Master Book, 2000.

SILVA, Maria Aracy Lopes da; RODRIGUES, Maria Carolina Young. Histórias de verdade. São Paulo: Secretaria Municipal de Cultura, 1992.

WERNER, David. Donde no hay doctor: guia para los campesinos que viven lejos de los centros medicos. Ciudad de Mexico: Editorial Pax-Mexico, 1973. 